\section{Spotlight on the October 5 Issue}

\author{
Robert A. Gross, MD, PhD, FAAN \\ Editor-in-Chief, Neurology ${ }^{\circledR}$
}

\section{Spontaneous MxA mRNA level predicts relapses in patients} with recently diagnosed MS

DDI

Baseline MxA mRNA levels were measured in a prospective cohort of 116 untreated, recently diagnosed MS patients and were related to clinical relapses and MRI at baseline and at follow-up. The authors found that MxA mRNA was related to clinical exacerbations and could be a potential biomarker for clinical disease activity in MS.

See p. 1228; Editorial, p. 1222

\section{Imaging distribution and frequency of cortical lesions in} patients with multiple sclerosis

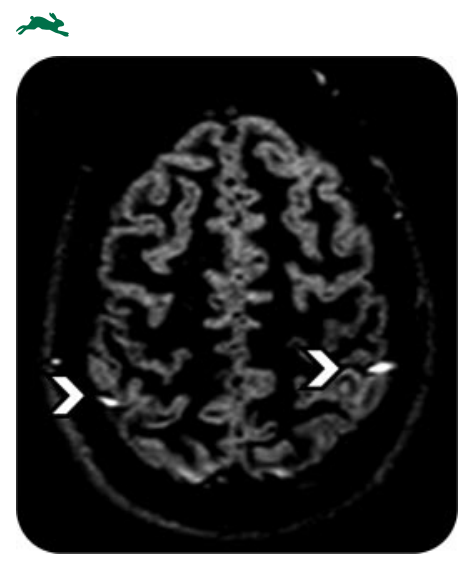

The authors examined MRIs, which included the double inversion recovery sequence for cortical lesions in 149 patients with multiple sclerosis. The findings were compared to histopathologic data and suggest that double inversion recovery images can show the focal pathology occurring in cortical regions of patients with multiple sclerosis.

See p. 1234; Editorial, p. 1224

\begin{abstract}
Cognitive compensation failure in multiple sclerosis
The authors performed an fMRI paradigm based on a Go/No-go task with increasing complexity and neuropsychological testing and morphologic MRI examinations on 15 patients with relapsing-remitting multiple sclerosis (RRMS) and 20 healthy controls. High cognitive demand caused cerebral recruitment failure, leading to cognitive impairment in patients with RRMS. See p. 1241
\end{abstract}

\footnotetext{
Assessment of potential measures in models of progression in Alzheimer disease

Subjects with mild to moderate Alzheimer disease (AD) were evaluated using the following scales: MMSE, disability assessment in dementia, clinical dementia rating, and dependence. In comparing their ability to explain variations in cognitive, functional, and behavioral measures, the disability assessment, clinical dementia, and dependence scales were better candidates for modeling AD progression.

\section{Effects of a central cholinesterase inhibitor on reducing falls in Parkinson disease \\ a) $\mathrm{A}$}

This randomized, placebo-controlled trial enrolled 23 patients with Parkinson disease who reported falling or nearly falling more than 2 times per week. During active treatment with the acetylcholinesterase inhibitor donepezil, there was a $48 \%$ reduction in fall frequency (measured by weekly reports). This exploratory investigation suggests cholinergic augmentation may benefit patients with Parkinson disease who fall.

See p. 1263

From editorialist J. Eric Ahlskog: The findings of this study are suggestive but hardly definitive. They clearly require replication and further delineation before donepezil could be recommended for treatment of fall risk in PD.

See p. 1226

What predicts mortality in Parkinson disease? A prospective population-based long-term study

A community-based prevalent sample of 230 patients with Parkinson disease was followed prospectively with repetitive assessments of motor and nonmotor symptoms from 1993 to 2005. In addition to age at onset, chronological age, motor severity, and dementia, psychotic symptoms independently predicted increased mortality in Parkinson disease.

See p. 1270

VIEWS \& REVIEWS

A meta-regression of the long-term effects of deep brain stimulation on balance and gait in PD

This review selected 13 articles that provided Unified Parkinson's Disease Rating Scale and postural instability and gait disability (PIGD) score before surgery and at follow-up 3 years after surgery. Deep brain stimulation (DBS) alone does not offer the same improvement to PIGD as it does to the cardinal symptoms, suggesting axial and distal control are differentially affected by DBS.

See p. 1292

NB: "Free CME while exercising? Thanks, AAN": Neurology ${ }^{\circledR}$ Podcasts

Podcasts can be accessed at www.neurology.org 


\title{
Neurology
}

\author{
In Focus: Spotlight on the October 5 Issue \\ Robert A. Gross \\ Neurology 2010;75;1221 \\ DOI 10.1212/WNL.0b013e3181f6f2bf
}

\section{This information is current as of October 4, 2010}

\section{Updated Information \&}

Services

Permissions \& Licensing

Reprints including high resolution figures, can be found at: http://n.neurology.org/content/75/14/1221.full

Information about reproducing this article in parts (figures,tables) or in its entirety can be found online at:

http://www.neurology.org/about/about_the_journal\#permissions

Information about ordering reprints can be found online:

http://n.neurology.org/subscribers/advertise

Neurology ${ }^{\circledR}$ is the official journal of the American Academy of Neurology. Published continuously since 1951, it is now a weekly with 48 issues per year. Copyright . All rights reserved. Print ISSN: 0028-3878. Online ISSN: 1526-632X.

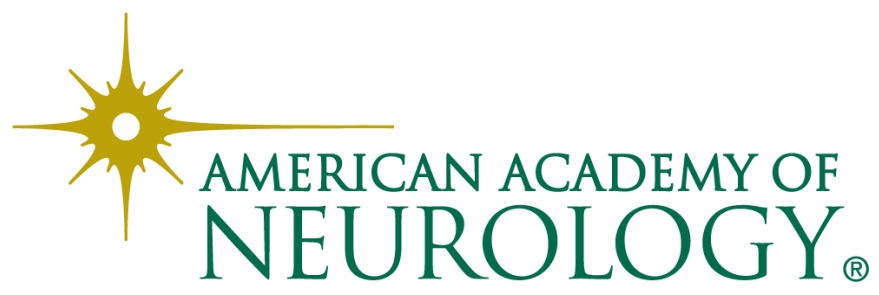

